(-) institute of development studies

Working Paper

Volume 2021 Number 557

Chinese-Funded Electricity Generation in Sub-Saharan Africa and Implications for Public Debt and Transition to Renewable Energy

Seife Ayele and Vianney Mutyaba

November 2021 
The Institute of Development Studies (IDS) delivers world-class research, learning and teaching that transforms the knowledge, action and leadership needed for more equitable and sustainable development globally.

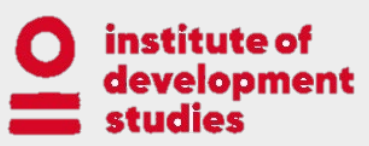

(C) Institute of Development Studies 2021

Working Paper Volume 2021 Number 557

Chinese-Funded Electricity Generation in Sub-Saharan Africa and Implications for Public Debt and Transition to Renewable Energy

Seife Ayele and Vianney Mutyaba

November 2021

First published by the Institute of Development Studies in November 2021

ISSN: 2040-0209 ISBN: 978-1-78118-885-9

DOI: $10.19088 /$ IDS.2021.063

Suggested citation: Ayele, S. and Mutyaba, V. (2021) Chinese-Funded Electricity Generation in Sub-Saharan Africa and Implications for Public Debt and Transition to Renewable Energy, IDS Working Paper 557, Brighton: Institute of Development Studies, DOI: 10.19088/IDS.2021.063

A catalogue record for this publication is available from the British Library

This paper is funded with UK aid from the UK government (Foreign, Commonwealth \& Development Office FCDO, formerly DFID). The opinions are the authors and do not necessarily reflect the views or policies of IDS or the UK government.

(c) (1) This is an Open Access paper distributed under the terms of the Creative Commons Attribution 4.0 International licence (CC BY), which permits unrestricted use distribution, and reproduction in any medium, provided the original authors and source are credited and any modifications or adaptations are indicated.

Available from:

Institute of Development Studies, Library Road

Brighton, BN1 9RE, United Kingdom

+44 (0)1273915637

ids.ac.uk

IDS is a charitable company limited by guarantee and registered in England

Charity Registration Number 306371

Charitable Company Number 877338 
Working Paper

Volume 2021 Number 557

Chinese-Funded Electricity Generation in Sub-Saharan Africa and Implications for Public Debt and Transition to Renewable Energy

Seife Ayele and Vianney Mutyaba

November 2021 


\section{Chinese-Funded Electricity Generation in Sub-Saharan Africa and Implications for Public Debt and Transition to Renewable Energy}

\section{Seife Ayele and Vianney Mutyaba November 2021}

\section{Summary}

While China has been increasingly contributing to the recent growth in electricity generation in sub-Saharan Africa (SSA), the effects of China-funded investment on host countries' debt burden and transition to renewable energy sources have not been sufficiently explored. Drawing on secondary data, combined with deep dive studies of Ethiopia and Uganda, this paper shows that despite significant liberalisation of the power sector in SSA, Chinese investments in the electricity industry continue to follow state-led project contract-based models. We show that this approach has failed to encourage Chinese firms to build compelling investment portfolios for competitive procurements within the region and, instead and inadvertently, it has exacerbated the debt burden of host country governments. In spite of the global drive towards climate resilient energy generation, Chinese funding of electricity generation in SSA is not sufficiently channelled towards modern renewable energy sources such as wind and solar power that could reduce vulnerability to climate change. While recognising that the private sector-led competitive model of power generation is not without limitations, we argue that SSA's electricity generation strategy that leads to less public debt and more climate resilience involves increased involvement of Chinese investment in the competitive model, with more diversification of such investment portfolios towards modern renewables such as wind and solar energy resources.

\section{Keywords}

Chinese-financing; renewable energy; electricity generation; public debt; climate change; independent power producers; China; Ethiopia; Uganda; sub-Saharan Africa. 


\section{Authors}

Seife Ayele is a Research Fellow at the Institute of Development Studies, United Kingdom. He is a development economist, and his work focuses on renewable energy, agriculture and agribusiness development, and enterprise development and employment. He leads the Matasa Fellows Network supporting young African researchers to develop policy-relevant research in youth employment. He has extensively published, including 'The Resurgence of Agricultural Mechanisation in Ethiopia: Rhetoric or Real Commitment?' (2021, Journal of Peasant Studies).

Vianney Mutyaba is the Manager of Pricing at Electricity Regulatory Authority, Uganda, responsible for managing the Uganda Electricity Supply Industry Tariff Structure, reviewing investment proposals, and promoting investment in renewable energy. His expertise includes public-private partnership management, project finance and risk assessment, climate finance, electricity tariff design, regulatory policy, and energy sector reforms. He has an MPhil in Development Finance from University of Stellenbosch and master's in Strategic Planning from Heriot Watt University. He is a Fellow at the Association of Chartered Certified Accountants (UK) and a Certified Expert in Climate and Renewable Energy Finance from Frankfurt School of Finance and Management. 


\section{Contents}

Acknowledgements

1. Introduction

1.1 Overview

$1.2 \quad$ Research methodology

1.3 Organisation of the paper

2. Sub-Saharan Africa electricity sector and its financing

2.1 Evolution and status of the African electricity sector

2.2 China as a bridge financier

2.2.1 Growth in Chinese financing of SSA power projects

2.2.2 Chinese financing of renewable energy projects

3. Chinese investment in the Ethiopian energy sector

3.1 The Ethiopian energy sector: drivers of reform and current status18

3.2 Chinese investment in Ethiopian electricity sector

4. Chinese investment in Uganda's energy sector

4.1 The Ugandan energy sector: drivers of reform and current status 23

4.2 Chinese investment in Uganda energy sector

5. Discussion and conclusion 


\section{Figures}

Figure 2.1 Number of Chinese power generation projects in SSA

Figure 2.2 Installed capacity of Chinese generation projects in SSA (MW)

Figure 4.1 Number of Ugandan IPPs, 1999-2020

\section{Tables}

Table 3.1 Some major Chinese-financed energy sector projects 


\section{Acknowledgements}

The authors gratefully acknowledge the critical comments received from $\mathrm{Dr}$ Samson Hadush whose input led to an improved final output.

This research was conducted with support from the UK Anchor Institution for the China International Development Research Network, funded by the UK's Foreign, Commonwealth \& Development Office (FCDO). The findings and conclusions contained herein are those of the authors and do not necessarily reflect positions or policies of UK Anchor Institution for the China International Development Research Network or the UK government. The authors remain responsible for any errors and omissions.

\section{Acronyms}

$\begin{array}{ll}\text { EEP } & \text { Ethiopian Electric Power } \\ \text { EEPCo } & \text { Ethiopian Electric Power Corporation } \\ \text { EPC } & \text { Engineering, Procurement and Construction } \\ \text { ESI } & \text { Electricity Supply Industry } \\ \text { GDP } & \text { gross domestic product } \\ \text { GTP } & \text { Growth and Transformation Plan } \\ \text { GW } & \text { gigawatt } \\ \text { IMF } & \text { International Monetary Fund } \\ \text { IPP } & \text { independent power producer } \\ \text { kWh } & \text { kilowatt hour } \\ \text { MW } & \text { megawatt } \\ \text { REFIT } & \text { renewable energy feed-in-tariffs } \\ \text { SSA } & \text { Sub-Saharan Africa } \\ \text { TW } & \text { terawatt } \\ \text { UEB } & \text { Uganda Electricity Board }\end{array}$




\section{Introduction}

\subsection{Overview}

Africa has rich but largely untapped energy resources. It has well over 10 terawatts (TW) of solar potential, 350 gigawatts (GW) of hydroelectric, 110GW of wind and an additional 15GW of geothermal (AfDB 2015). However, electricity consumption per capita in sub-Saharan Africa (SSA) stands at 483-kilowatt hour (kWh), which is very low compared to other regions. South Asia, for example, stands at $707 \mathrm{kWh}$ and the Middle East and North Africa at 1,687 kWh (Blimpo and Cosgrove-Davies 2019). Although estimates vary, close to 600 million people in Africa (representing about 48 per cent of the continent's population of nearly 1.2bn) still have no access to power (IRENA 2019; IEA 2020).

Fuelled by economic growth (notably since the turn of the century) and population growth, demand for electricity is growing fast and it is estimated that it will increase by 100 per cent in the period 2018-30 (IRENA 2019). The African Development Bank (AfDB 2019) estimates that Africa needs approximately US\$32-40bn annual investment in electricity between 2018 and 2030. Low levels of electricity generation and use have been impeding socio-economic development in the region, and SSA cannot run its homes and businesses unless it unlocks its huge renewable energy potential (AfDB 2015).

The low level of supply is linked to multiple factors, including a lack of generating capacity, and limited transmission and distribution infrastructure. Drought and climate change have also been increasingly threatening generation from hydropower (IEA 2014; World Bank 2018). Additionally, poor electricity supply reduces utility revenues, makes it more difficult to increase tariffs, and thereby constrains the availability of finance for investment (IEA 2014).

National and global commitments for transitioning energy to low carbon emission technologies to mitigate and combat the adverse impacts of climate change have recently increased (see for example, Carbis Bay G7 Summit Communiqué 2021). In recent years, the emphasis for the majority of foreign direct investments has been on renewable energy and endeavours to align development of electricity infrastructure to the United Nations Sustainable Development Goals. The Economic Commission of Africa actively supports the transition from carbon-intensive and unsustainable technologies to clean and renewable technologies (UNECA 2014; IEA 2020). Commitments include attainment of net zero emissions no later than 2050 , halving collective emissions over the two decades by 2030 , increasing climate finance, and reaffirming commitment to the Paris Agreement (Carbis Bay G7 Summit Communiqué 2021). 
As we will show below, China has become a dominant force in the African electricity industry (Eberhard et al. 2016; Eberhard et al. 2017; Lema et al. 2021). But any investment in the sector, we argue, needs to address the perennial problems of lack of access to finance and the risk of utilities, and by extension SSA countries, becoming overly indebted. These have been major challenges and the subject of reform agendas in many SSA countries (World Bank 2018; Shendy, Kaplan and Mousley 2011). Consequently, many SSA governments have been addressing their investment needs through multiple mechanisms including their own resources, such as taxes and user charges, bilateral and multilateral donors, and development finance institutions (Eberhard et al. 2016). Yet many commentators have forcefully underlined the importance of private finance for investment - which comes via electricity procurement by independent power suppliers (Eberhard et al. 2016). Related to this, over the past decade, two models of financing have prevailed in SSA: Chinese investment following the so-called Engineering, Procurement and Construction (EPC) model, and investment by independent power producers (IPP) (Eberhard et al. 2016; Eberhard et al. 2017). While arguably IPPs encourage cost discovery and reduction (IRENA and CEM 2015; Eberhard et al, 2016), the EPC model has been favoured by Chinese investors (see, for example, Eberhard et al. 2016) leading Africa to make a significant addition to power generation in the region (Eberhard et al. 2016) - to a total of 7.5GW in installed capacity, most of which was added between 2009-14. While 63 per cent of this comprised of large hydropower projects, only 3 per cent came from wind power (Eberhard et al. 2017: 392). Due in part to this investment, the electricity access rate for SSA has improved from 23 per cent in 2000 to 32 per cent in 2012 (IEA 2014, 2020).

Our analysis of the phenomenal increase in Chinese investment and contribution is situated within the 'China in Africa' debate which has documented the historical context of Chinese engagement in Africa, notably since the late 1970s, and the multiple features of China's investment in (or engagement with) Africa (see, for example, Kaplinsky and Morris 2009; Gu 2009; Mohan 2013; Chiyemura 2019). This paper, however, propels the debate to the present, looking at some less explored areas of Chinese involvement in African electricity generation - its effects on public debt and transition to more diverse renewable energy sources.

We refer to 'Chinese investment' to mean investment capital originating in China, often channelled through Chinese businesses - state or privately owned, or some combination of both - to implement projects in SSA. Such investment is often backed by the so-called 'Chinese policy banks' (Shen and Power 2017; Lema et al. 2021). This resonates with what Kaplinsky and Morris (2009), Lema et al. (2021) and others call the 'Chinese model' - characterised by designing, constructing and delivering (turnkey) projects, deploying labour and equipment imported from China. The financing of such projects comes in a package of long- 
term concessionary loans to host countries from Chinese policy banks such as EXIM Bank. The Chinese firms are thus not 'investors' in the classic sense, nor do they own project assets.

Lema et al. (2021) is among recent studies on such investment in SSA and found that Chinese firms acting as main contractors accounted for 30 per cent of new capacity additions in sub-Saharan Africa. Of these projects, 56 per cent were in renewable energy, with the vast majority in hydropower, but increasingly also in wind and solar energy. Lema et al.'s in-depth analysis of economic cobenefits created when renewable-energy projects were developed by Chinese investors showed the rather limited outcomes of Chinese investment on local jobs and content use (Lema et al. 2021). Shen and Power (2017) and TanMullins, Urban and Mang (2017) showed multiple drivers of Chinese investment in Africa. Departing from earlier narratives, for example, around 'China's growing need for resources' (Kaplinsky and Morris 2009), these recent studies highlight the desire of Chinese firms for global positioning, backed by the Chinese government's 'going out' strategy, increasing domestic competition within China, and the declining number of investment opportunities in China as key drivers. Profit-seeking motivation was also a central feature (Tan-Mullins et al. 2017).

Finally, Chiyemura (2019), based on his in-depth study of two wind farms in Ethiopia, showed that Chinese investors complete projects quickly and at low cost. He also showed the willingness of China to reschedule and/or cancel debt, offering loans at concessionary rates (Chiyemura 2019). He argues that Chinese investment improves infrastructure and increases revenue for Ethiopia, with huge socio-economic and developmental implications (Chiyemura 2019). As clearly highlighted by Chiyemura (2019), African partners are not passive recipients of Chinese investment either. Chiyemura articulates that Ethiopians, for example, through their policies, were the main drivers of the development of their rich resources (such as wind) and were tapping into a range of global renewable energy technologies.

While significant research has been conducted on electricity generation through Chinese investment, these studies have paid little attention to the effects of such investment on utilities and host government debts and building climate resilient energy systems. This paper therefore aims to fill this gap, and address the following overarching questions: what is the trend and structure of Chinese investments in the SSA power sectors, and how does this compare with financing by independent power producers in the region? What are the implications of such investment on utilities and host government debts, and building climate resilient energy systems in SSA? 


\subsection{Research methodology}

Chinese investment in electricity generation is unevenly spread across subSaharan Africa (IEA 2014: 24) but, as noted above, in many countries it has made major impacts, particularly in countries where such investment has been actively taken up. We use data from secondary sources generated from international organisations such as the International Energy Agency (IEA) and the International Renewable Energy Agency (IRENA) at SSA level, coupled with deep dive case studies of Ethiopia and Uganda - two countries that have attracted significant Chinese investment. Over the past 10 or so years, Ethiopia has implemented several Chinese-financed projects, including the first early wind farms in Africa (Chiyemura 2019). But despite plenty of opportunities, Chinese investment has shied away from being involved in Ethiopia's recently developing IPPs. On the other hand, Uganda was among the first SSA countries to undertake energy reform (Godinho and Eberhard 2019) and hosts the second largest number of IPPs in SSA after South Africa (Eberhard et al. 2016). Uganda also has significant Chinese-financed projects in the electricity sector, with two large hydropower plants developed by the Chinese. Ethiopia and Uganda therefore constitute rich cases for exploring the effects of Chinese investments in the region.

\subsection{Organisation of the paper}

The paper is organised as follows. Section 2 presents and analyses data on electricity generation in SSA, specifically looking the contribution of Chinese finance. Sections 3 and 4 present the energy sector power reforms and the status of power generation capacities in Ethiopia and Uganda, respectively. It discusses Chinese financed projects in both countries and implications for national debt and climate change. Finally, section 5 comprises the discussion and conclusion, along with policy implications and recommendations of the study. 


\section{Sub-Saharan Africa electricity sector and its financing}

\subsection{Evolution and status of the African electricity sector}

Prior to the year 2000, investment in electricity generation in many SSA countries was the preserve of governments - often financed through budgetary allocations and sovereign debt, including concessionary loans from development finance institutions (Meyer, Eberhard and Gratwick 2018; Wamukonya 2005). The SSA state dominance in electricity development during the period 1990-2001 meant that the private sector accounted for only 13 per cent of investment in Africa's electricity sector (Wamukonya 2005). SSA governments struggled to mobilise financing - as Eberhard et al. (2016) show, investment in electricity generation was not only low but narrowly focused on South Africa. Between 1990-2013, only $24.85 \mathrm{GW}$ of new generation capacity was added across SSA, of which $9.2 \mathrm{GW}$ or 37 per cent was accounted for by South Africa. Over the same period, investments in new power generation capacity reached approximately US\$45.6bn, of which US\$14.3bn (or 31 per cent) was accounted for by South Africa. Eberhard et al. (2016) also show that, of the total investment of US\$31.3bn over 1990-2013, IPPs and Chinese investment accounted for 22 per cent and 16 per cent respectively, while the remainder was contributed by national governments and utilities (51 per cent) and international financial institutions (11 per cent).

Insufficient public funds, coupled with poor performance of state utilities, forced many governments in SSA to change their financing approach (Meyer et al. 2018). Consequently, many countries undertook structural and policy reforms, including the unbundling of vertically integrated state corporations, liberalisation of the sector and establishment of independent regulatory bodies, in order to encourage private sector participation (Eberhard et al. 2016; Meyer et al. 2018). Eberhard et al. (2016) underlines that by 2014 , more than half of SSA countries had established a regulatory agency. As we will show below, Uganda and Ethiopia were among those countries that implemented such policy reforms.

In many SSA countries, the energy sector reform aimed to attract private sector investments - which require an enabling environment offering long-term investment certainty. This meant implementing policies that guaranteed the full recovery of costs through end-user tariffs (Meyer et al. 2018). Cost reflective tariff reforms became central to attracting private investment, but present stiff challenges as they can overburden the majority of household consumers who are poor and less able to pay for their electricity bills (Blimpo and Cosgrove-Davies 2019). 


\subsection{China as a bridge financier}

\subsubsection{Growth in Chinese financing of SSA power projects}

Over the past two decades, power sector reforms in SSA have been primarily driven by the need to attract private financing for investments in energy infrastructure to boost the limited generation capacity and enhance electrification rates, amidst insufficient public funds and historical underperformance by state owned utilities (Meyer et al. 2018; Wamukonya 2005). However, despite the optimistic outlook on reform, privatisation has not been successful at attracting affordable private capital in many SSA power sectors (Eberhard et al. 2016). Infrastructure development requires large upfront financing - with investment repayment spread over a larger base and longer periods, which is difficult for SSA. Consequently, many countries in SSA developed a negative perception towards private sector participation and investment (Wamukonya 2005). In order to address power generation financing requirements, and at the same time ensure low retail electricity tariffs, many SSA governments looked to Chinese financed EPC projects (Eberhard et al. 2016). Moreover, as Africa attracted private investment to develop generation capacity, China did not participate in the IPP programmes (Power Futures Lab 2020). As shown in Eberhard et al (2016), as most African countries were unable to finance their power needs, the financing of electricity generation capacity increasingly shifted to Chinese financed EPC models. Eberhard et al. (2016) state that while many SSA countries had previously procured generation capacity through competitive procurement and its attendant benefits, when it came to China, many SSA countries preferred direct negotiations.

Statistics are limited and varied, but in recent years China has clearly emerged as the leader in Africa's power sector developments, accounting for 60 per cent of investments in SSA power projects (Lema et al. 2021). Lema et al. (2021) reported Chinese investments in Africa of US\$30bn, including North Africa and all sources of energy (of this amount, US\$13bn was deployed for renewable projects in 37 countries) ${ }^{1}$. Power Futures Lab (2020) reports that the value of Chinese investments in power generation in SSA is now more than investments by typical IPPS. Chinese financing has increased from US\$0 (zero) in 1997 to almost US $\$ 6$ bn in 2018 , compared to US $\$ 4$ bn by IPPs during the same period (Power Futures Lab 2020).

According to Acker, Brautigam and Huang (2021), China is Africa's largest bilateral creditor responsible for at least 21 per cent of African debt - and payments to China account for nearly 30 per cent of 2021's debt service. The

\footnotetext{
1 In the same vein, Cabré, Gallagher and Li (2018) provides an estimate of US\$216bn since 2000, inclusive of investments in fossil fuels and renewable energy.
} 
World Bank and other multilaterals are responsible for 20 per cent of African debt. Estimates also show that one-third of countries in SSA were either in or at risk of debt distress even before the onset of the Covid-19 pandemic, which has since worsened (Coulibaly 2021).

International financial institutions such the International Monetary Fund (IMF) estimate that SSA will need an additional \$345bn through 2023. Accordingly, 38 countries in SSA are eligible for relief under the G20's debt service suspension initiative. Growing debt, therefore, suggests that the bilateral country to country approach used by China to finance power projects in SSA may not be sustainable in the medium to long term (Acker, Brautigam and Huang 2021; Coulibaly 2021).

The growth of Chinese finance in the power sector needs to be seen in context and as a continuation of growth in overall trade and investment in SSA. Since 2000, China has emerged as Africa's largest trading partner (Chen, Dollar and Tang 2018). According to the China Africa Research Initiative (2021), the value of China-Africa trade in 2019 was US\$192bn, up from US\$185bn in 2018. With respect to power generation, the IEA (2016) states that Chinese investment is responsible for 30 per cent of new generation capacity in SSA between 2010 and 2015, and Chinese firms built 17GW of generation capacity in SSA between 2010 and 2020. On the other hand, Shen (2020) asserts that Chinese power development companies have moved into SSA because of the saturated Chinese domestic market and competition from project developers from Europe and US markets.

\subsubsection{Chinese financing of renewable energy projects}

China is the powerhouse of renewable energy technologies, notably solar energy technologies. Eight of the top 10 world suppliers are Chinese, yet China has made limited contribution to harnessing Africa's renewable energy (Ayele et al. 2021). Whereas China has investment in power generation in SSA across the different technologies, most projects and capacity is invested in large hydropower plants (Eberhard et al. 2017; IEA 2016), as illustrated in Figures 2.1 and 2.2 below. Other statistics by International Rivers (2019, as cited in Lema et al. 2021) indicates that there are more than 85 hydropower projects financed by China in Africa. 


\section{Figure 2.1 Number of Chinese power generation projects in SSA}

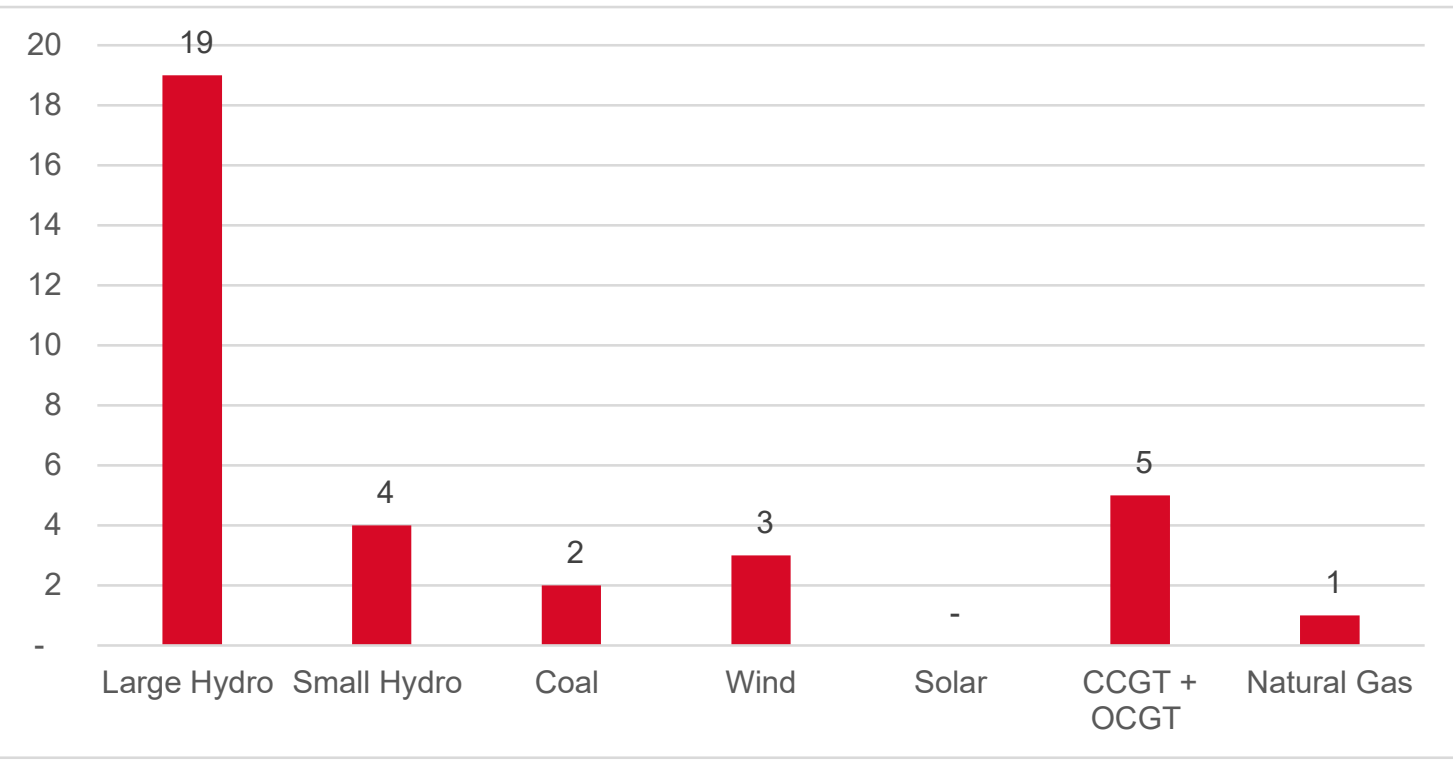

Source: Authors' own. Computation based on Eberhardt et al. (2017)

\section{Figure 2.2 Installed capacity of Chinese generation projects in SSA (MW)}

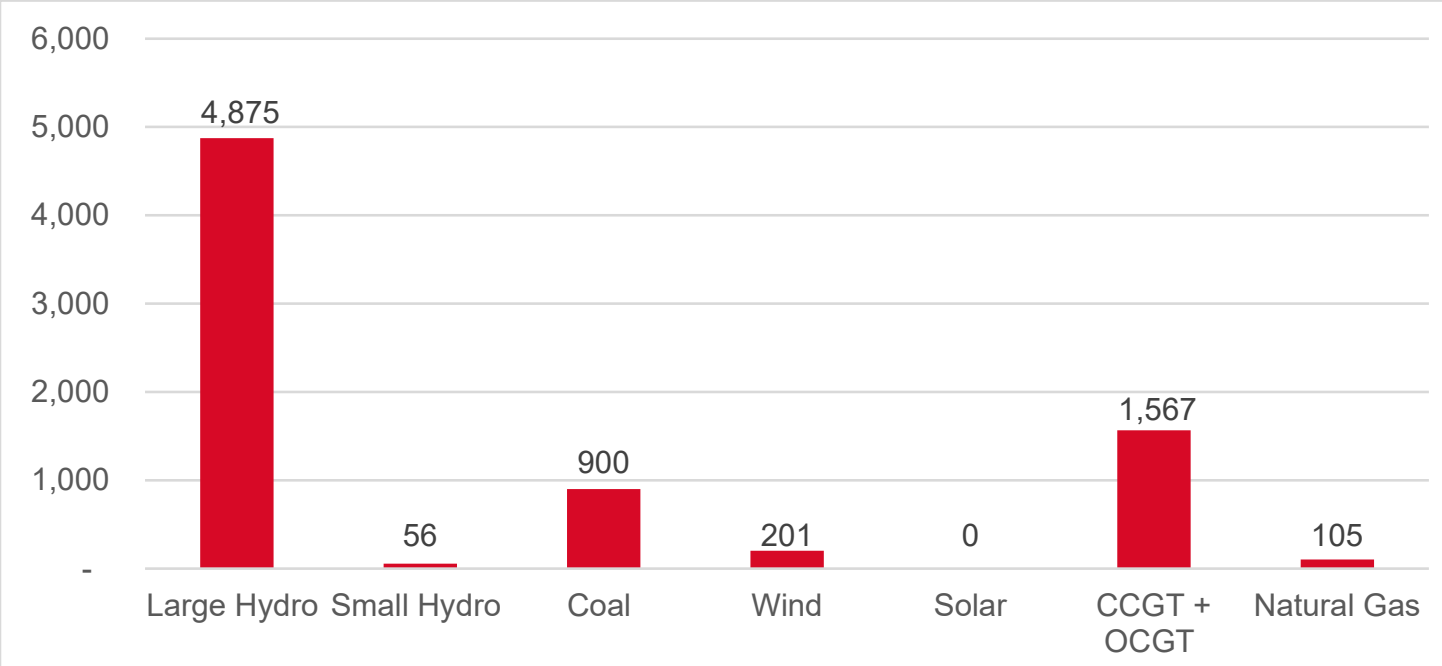

Source: Authors' own. Computation based on Eberhard et al. (2017)

The dominance of large hydropower plant development is confirmed by Lema et al. (2021) - Chinese investors accounted for 60 per cent of hydropower investments in SSA. But the Chinese appetite for investments in solar and wind power generation in SSA has not been as high as the exhibited interest for these technologies within China. By 2017, China had developed 19 large hydropower plants, four small hydropower plants, three wind plants, and zero solar projects in Africa (Eberhard et al. 2017; Figure 2.2). Also, as discussed by Eberhard et al. 
(2016), in SSA countries small renewable energy projects are increasingly procured through auctions and renewable energy feed-in-tariffs (REFIT) though the results have been disappointing, with relatively few projects developed. However, for the reasons we discuss below, Chinese firms have not been responsive to competitive procurement of power plants in SSA. Shen (2020) notes that whereas Africa has transitioned to competitive bidding systems, China still prefers direct bilateral negotiations with Africa rather than open bidding and auction schemes, even in countries where auction and REFIT frameworks exist. 


\section{Chinese investment in the Ethiopian energy sector}

\subsection{The Ethiopian energy sector: drivers of reform and current status}

With over 117 million inhabitants in 2021, Ethiopia is the second most populous country in Africa after Nigeria. Its government is a federal parliamentary republic, with 10 self-governing regions. About 80 per cent of Ethiopians live in rural areas. From early 2000 , the government embraced the 'developmental state' approach and played an active role in the economy, implementing two successive Growth and Transformation Plans (GTP-I and GTP-II) (Ayele 2021). For most of the past two decades, the Ethiopian economy registered double digit growth, averaging 9.9 per cent a year from 2007/8-17/18. Currently classified as a low-income economy by the World Bank, Ethiopia aims to attain low middleincome country status by 2025 (Ayele 2021). Following Abiy Ahmed's taking the premiership position in 2018, the party that ruled Ethiopia for nearly three decades - the Ethiopian People's Democratic Revolutionary Front - was dissolved in 2019 and replaced by the Prosperity Party. Prime Minister Abiy Ahmed and the Prosperity Party continue the liberalisation of the electricity sector, including procuring electricity through Independent Power Producers (IPPs) (MoFEC 2017).

For over 120 years, Ethiopia has been generating electricity, but by the end of the twentieth century its capacity had never exceeded 1,000MW (MoWIE 2019). Successive reforms have been undertaken to address perennial challenges (MoWIE 2019; Teferra 2002).

First, in 1997, the state-owned Ethiopian Electric Light and Power Authority (ELPA) was split into the Ethiopian Electric Power Corporation (EEPCo), to generate, transmit, distribute, and sell electricity; and the Ethiopian Electricity Authority (EEA), to regulate the sector. The reform made EEPCo seemingly independent of its line ministry, to reduce bureaucratic delays in key decision making and determine tariff rates based on commercial principles. Second, in 2013, there was a further restructuring of the state energy company and EEPCo was unbundled into the Ethiopian Electric Power (EEP) and Ethiopian Electric Utility (EEU) (Baker et al. 2021, forthcoming). In the same vein, in 2017, a public private partnership (PPP) mechanism was put in place to promote private sector investment in the power sector and facilitate the implementation of privately financed infrastructure projects, including procuring renewable energy from independent power producers (RE-IPP) (MoFEC 2017). Finally, many allied reforms have been undertaken, including quality service improvement in revenue 
collection, electricity tariff reforms, and capacity building programmes (MoWIE 2019).

The above reforms were precipitated by a range of drivers (World Bank 2018; MoWIE 2019):

- Increased demand for investment - utility companies were dependent on public finances with a high level of indebtedness.

- Limited ability to switch to non-hydropower renewable sources and meet ambitious targets in GTPs.

- Unreformed tariff rates which failed to reflect production costs and demand.

- Droughts and climate change threatening generation from hydropower sources.

- A growing need to transition towards a cleaner energy system, as nearly 80 per cent of the population were dependent on unsustainable traditional biomass energy sources.

Reform measures have started to pay off - for example, generation capacity grew from 380MW in 1991 to 850MW in 2009 and reached 4,413MW in 2020 (MoWIE 2019; MoWIE 2020; Tesfamichael et al. 2021). With the Grand Ethiopian Renaissance Dam (GERD) and other major projects in the pipeline, Ethiopia is set to generate 21,238MW by 2030 (MoWIE 2020). However, despite being endowed with abundant renewable resources, only 44 per cent of over 117 million Ethiopians have access to electricity, and this gives Ethiopia the second largest electricity access deficit in SSA (MoWIE 2019). Yet Ethiopia aims to reach 100 per cent by 2025 - if realised, this will mean achieving Goal 7 of the UN Sustainable Development Goals ('ensure access to affordable, reliable, sustainable and modern energy for all') five years early.

\subsection{Chinese investment in Ethiopian electricity sector}

Ethiopia has abundant and diverse renewable energy resources in hydropower, solar, geothermal, and wind energy (MoWIE 2019), but it has not sufficiently exploited its resource advantage. For example, it has 45,000MW exploitable hydropower, but use remains below 10 per cent of potential (MoWIE 2019). Exploitation of the huge potential of solar, geothermal, and wind sources is negligible. Consequently, Ethiopia's energy supply is highly dependent on biomass resources - firewood and agricultural waste (MoWIE 2018). 


\section{Table 3.1 Some major Chinese-financed energy sector projects ${ }^{2}$}

\begin{tabular}{|c|c|c|c|c|c|}
\hline $\begin{array}{l}\text { Project } \\
\text { name and } \\
\text { sector }\end{array}$ & $\begin{array}{l}\text { Year } \\
\text { Completed }\end{array}$ & $\begin{array}{l}\text { Project } \\
\text { size }\end{array}$ & $\begin{array}{l}\text { Main } \\
\text { Contractor } \\
\text { or } \\
\text { Financers } \\
\end{array}$ & $\begin{array}{l}\text { Total } \\
\text { Project } \\
\text { cost } \\
\text { (US\$ m) }\end{array}$ & $\begin{array}{l}\text { Chinese } \\
\text { Contribution } \\
\text { (in \%) }\end{array}$ \\
\hline $\begin{array}{l}\text { Tekeze } \\
\text { hydro } \\
\text { project }\end{array}$ & 2002 & 300MW & $\begin{array}{l}\text { SinoHydro \& } \\
\text { Gezhouba }\end{array}$ & 365 & $\mathrm{~N} / \mathrm{A}$ \\
\hline $\begin{array}{l}\text { Finchaa- } \\
\text { Amerti- } \\
\text { Neshe- } \\
\text { hydro }\end{array}$ & 2007 & 97MW & C-EXIM & 155 & $75 \%$ \\
\hline $\begin{array}{l}\text { Adama I - } \\
\text { wind }\end{array}$ & 2009 & $51 \mathrm{MW}$ & C-EXIM & 117 & $85 \%$ \\
\hline $\begin{array}{l}\text { Adama II - } \\
\text { wind }\end{array}$ & 2011 & 153MW & $\begin{array}{l}\text { China } \\
\text { Gezhouba } \\
\text { Group } \\
\text { Comp } \\
\text { (CGGC) }\end{array}$ & 345 & $85 \%$ \\
\hline $\begin{array}{l}\text { Gibe 3, } \\
\text { hydro - } \\
\text { electric \& } \\
\text { hydro- } \\
\text { mechanics }\end{array}$ & 2010 & $\begin{array}{l}\text { 1870M } \\
\text { W }\end{array}$ & ICBC & 1888 & $25 \%$ \\
\hline $\begin{array}{l}\text { Genale- } \\
\text { Dawa } 3- \\
\text { hydro }\end{array}$ & 2010 & $254 \mathrm{MW}$ & C-EXIM & 455 & $60 \%$ \\
\hline $\begin{array}{l}\text { Genale- } \\
\text { Dawa 3- } \\
\text { Trans- } \\
\text { mission }\end{array}$ & 2010 & $\begin{array}{l}\text { Trans- } \\
\text { mission }\end{array}$ & C-EXIM & 250 & $\mathrm{~N} / \mathrm{A}$ \\
\hline $\begin{array}{l}\text { Aba } \\
\text { Samuel - } \\
\text { hydro }\end{array}$ & 2010 & & $\begin{array}{l}\text { Power } \\
\text { China/ } \\
\text { Huagog } \\
\text { Eng. Corp } \\
\text { Ltd }\end{array}$ & 94.7 & \\
\hline Total & & 975MW & & 3669.7 & \\
\hline
\end{tabular}

Sources: Authors' own. Created using data from Chiyemura (2019) and unpublished 2020 data from Ethiopian Electric Power (EEP).

\footnotetext{
2 Note that many more projects built (or planned) with finance from International Finance Institutions and own sources are not listed here.
} 
Spearheaded by EEP, several electricity generation projects have been completed, and many more are in the pipeline. Table 3.1 above shows partial data where Chinese finance has had some effects. Table 3.1 indicates that:

- Power generation has picked up over the past two decades, with Chinese businesses involved in the generation of at least 975MW (out of 4,413MW recent generation capacity).

- Chinese business involvement was mainly in hydro projects, with some in wind plants.

- Six hydro projects: Tekeze (300MW), Finchaa-Amerti-Neshe (97MW), Gibe III (1870MW), Genale-Dawa (254MW), Genale-Dawa (transmission project) and Aba Samuel Dam.

- Two wind farms: Adama I (51MW), Adama II (153MW)

- The share of Chinese investment in total project varied but, except for the Genale-Dawa transmission project where it was over 60 per cent. In all three wind plants, Chinese finance accounted for 85 per cent.

- For the above projects, Chinese investment exceeded \$US2bn.

- EEP (and by extension the Government of Ethiopia) is liable for the loan. This is because EEP (the Government) own the dams and wind plants. Chinese companies, as per EPC agreement, only design, construct, and deliver the projects to EEP.

The foregoing clearly indicates the significance of the contribution made by Chinese businesses to electricity generation in Ethiopia. It also indicates how Chinese investments have added to the debt burden of the utility company and the government. When the privatisation agenda was pushed but garnered little interest from private sector finance, China stepped in and eased the financial pressure, but inadvertently added to the debt burden. Debt has become unsustainable and there have been high level debt rescheduling discussions between Ethiopian and Chinese governments officials. Fox (2019) reported that the Ethiopian Prime Minister Abiy Ahmed opened up such negotiations with China to restructure previous deals. In September 2018, he reached an agreement with China to restructure the repayment period of loans from 10 to 30 years (Fox 2019) ${ }^{3}$.

Section five will discuss the reasons why Chinese businesses prefer EPC projects that lead to public debt for host governments like Ethiopia, but here we make two conclusions: first, Ethiopia's electric sector reform primarily focused on procurement of electricity from diverse resources and suppliers. While China

\footnotetext{
3 Significant debt - state policy banks extended it to more than $\$ 12.1 \mathrm{bn}$ since 2000 , according to the China Africa Research Initiative at Johns Hopkins University of the United States (Fox 2019).
} 
responded well - through increased engagement in the Ethiopian energy market - its investment was limited to undertaking EPC contracts. In doing so, it exacerbated the debt burden of the treasury and offtaker. Second, although Chinese businesses have entered the wind farm sector, thus far they have shied away from utility level energy generation from solar and geothermal resources. 


\section{Chinese investment in Uganda's energy sector}

\subsection{The Ugandan energy sector: drivers of reform and current status}

Uganda, a landlocked country in East Africa, has a population of 44.27 million (Blimpo and Cosgrove-Davies 2019). According to UBOS (2020), 76 per cent of the Ugandan population live in rural areas, and the gross domestic product (GDP) annual growth rate in Uganda averaged 5 per cent from 2009-20. The World Bank classifies Uganda as a low-income country. In 2018, 51 per cent of Ugandan households had access to at least one source of electricity, with 24 per cent of households accessing it through the national grid, and 27 per cent accessing it through off-grid solutions (UBOS 2018).

The Uganda electricity sector faced an energy crisis in the 1990s, in the aftermath of the challenges of the 1971-86 emergency period and declining water levels in Lake Victoria (Meyer et al. 2018). The government initiated a reform programme in the late 1990s seeking to address the pressing issues faced by the electricity supply industry. Before this reform process began, the industry predominantly consisted of the Uganda Electricity Board (UEB) which had been the publicly owned vertically integrated utility since 1948 and had a monopoly in providing generation, transmission, and distribution of electric power. It also had export agreements with some neighbouring countries, as well as a regulatory role. The performance of UEB was perceived to be inadequate, resulting in an industry that was underfinanced and delivering poor service.

Uganda became the first country in SSA to unbundle generation, transmission and distribution of electricity (Eberhard et al. 2016). The reforms came with the backdrop of slow growth in investments in the Electricity Supply Industry (ESI) mainly the generation infrastructure and the associated transmission and distribution infrastructure, and the need to improve the financial sustainability and operational efficiency of the ESI. The main drivers justifying the need for reform have been described as (MEMD 2002; Meyer et al. 2018):

- Low electricity sector efficiency, characterised by (a) high level of system losses (up to 38 per cent), and (b) unreliable and poor quality of power supply constraining business development.

- Very low coverage and poor access to the grid.

- The UEB's inability to service its debts. 
- The need for private sector-led economic growth, resulting in the desire to minimise monopoly power.

- The need to attract private capital.

The core reform and restructuring process initiated by the 1999 Electricity Act took some six years to implement. In 2000, the Electricity Regulatory Authority (ERA) was established, and in 2001, the formal unbundling of UEB commenced. In 2002, the Energy Policy described above was published to support the 1999 Electricity Act and facilitate private investment (MEMD 2002). The state-owned corporation, UEB, was unbundled into three distinct corporations to oversee the generation, transmission, and distribution of electricity on behalf of government. The distribution and generation assets were respectively privatised to Umeme Limited in 2005 and Eskom Uganda limited in 2003, marking the entry of independent power producers in Uganda's ESI (Meyer et al. 2018). Even as the reforms took root and inefficiencies were tackled through privatisation, there was some inertia in investments in generation capacity. In order to address generation capacity shortages, Uganda competitively procured Bujagali Hydropower Plant. When Bujagali Hydropower Plant was commissioned in August 2012, it helped avert loading shedding and provided replacement generation from the expensive thermal plants. The commissioning of Bujagali Hydropower Plant, the eventual reduction of direct electricity subsidies, as well as restructuring of the investment framework with the review of Feed-In-Tariffs (FiTs), created the impetus to attract investment in renewable energy production (Meyer et al. 2018; Eberhard et al. 2016).

Like many SSA countries, since 2007 has Uganda implemented REFIT to attract private investment in renewable energy. It also procured solar plants under a competitive tendering programme. Eberhard et al. (2016) states that whereas critics argued that the Uganda electricity supply industry was too small to reap the benefits of the reforms, they are now bearing fruit (Figure 4.1). The number of IPPs in Uganda increased from three in 1999 to 47 in 2020. Uganda has attracted IPPs on account of its stable regulatory framework that ensures cost reflective tariffs, and a streamlining of the licensing process. Godinho and Eberhard (2019) noted that Uganda is one of the few SSA countries with close to cost reflective tariffs. In Uganda, before 2012, the electricity retail tariff was heavily subsidised, with the government paying 56 per cent of the costs. According to Eberhard et al. (2016), the establishment of a regulator is an enabling factor for boosting IPP investments. 


\section{Figure 4.1 Number of Ugandan IPPs, 1999-2020}

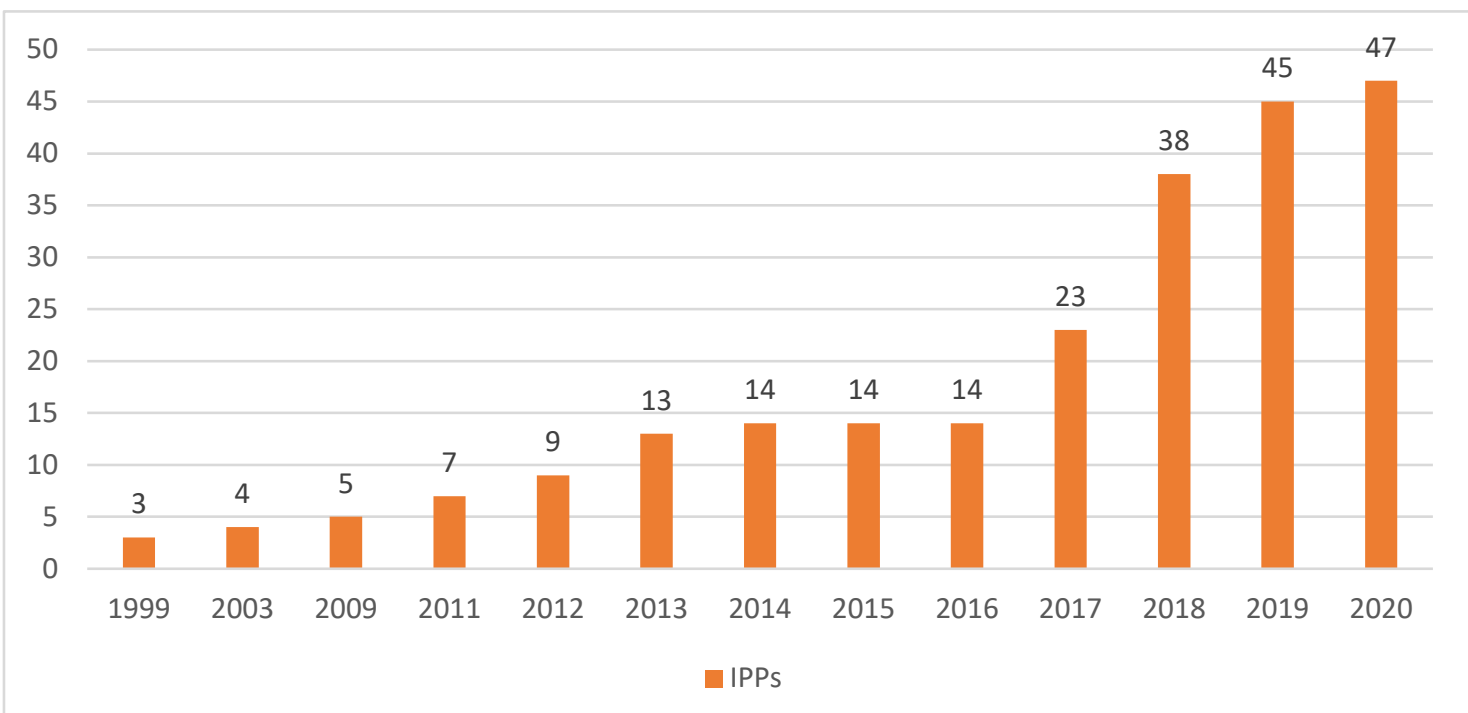

Source: Authors' own. Created using data from Electricity Regulatory Authority (2021).

The effects of the reform measures have been reflected in Uganda's installed capacity, which increased from 394.9MW in 2009 to $1,268 \mathrm{MW}$ in 2020 and is expected to reach over 2,000MW by mid-2022, with the commissioning of the Karuma Hydropower Plant. The distribution energy losses reduced from 33 per cent in 2005 to 16.4 per cent in 2019 , and revenue collection has increased from 82.8 per cent in 2005 to 100 per cent by 2019 .

\subsection{Chinese investment in Uganda energy sector}

Following the commissioning of Bujagali Hydropower Plant in 2012 and subsequently other IPPs, Uganda noted that the generation tariffs for IPPs, and by extension the resultant retail tariffs, were not supporting the country's industrialisation aspirations. Despite government's efforts, the private sector attached high risk to investment in the sector and demanded high generation tariffs, contrary to government expectation. However, without reversing its policy to attract private investment, Uganda turned to China to finance development of the 183MW Isimba hydropower project (commissioned in March 2019), and the $600 \mathrm{MW}$ Karuma hydropower project (to be commissioned in June 2022). Unlike the 250MW Bujagali Hydropower Plant, the Isimba and Karuma plants were contracted through bilateral direct negotiations between Uganda and China ${ }^{4}$. As part of the project structure, the EPC contractor was from China, the loans were from China Exim Bank, and Uganda was required to make a 15 per cent upfront contribution to the EPC costs (Meyer et al. 2018).

\footnotetext{
${ }^{4}$ Here we note that, despite active participation in Uganda power generation, China has not participated in competitive procurement in Uganda or development generation projects other than large hydropower.
} 


\section{Table 4.1 Chinese-financed energy sector projects in Uganda}

\begin{tabular}{|l|l|l|l|l|}
\hline Project & $\begin{array}{l}\text { EPC - } \\
\text { US\$m }\end{array}$ & $\begin{array}{l}\text { Loan - } \\
\text { US\$m }\end{array}$ & Status & $\begin{array}{l}\text { Method of } \\
\text { procurement }\end{array}$ \\
\hline $\begin{array}{l}\text { 183MW } \\
\text { Isimba } \\
\text { Hydropower } \\
\text { Project }\end{array}$ & 576.7 & 482.5 & $\begin{array}{l}\text { Commissioned } \\
\text { March 2019 }\end{array}$ & $\begin{array}{l}\text { Direct } \\
\text { bilateral } \\
\text { negotiation }\end{array}$ \\
\hline $\begin{array}{l}\text { 600MW } \\
\text { Isimba } \\
\text { Hydropower } \\
\text { Project }\end{array}$ & $1,688.4$ & $1,435.1$ & $\begin{array}{l}\text { To be } \\
\text { commissioned } \\
\text { June 2022 }\end{array}$ & $\begin{array}{l}\text { Direct } \\
\text { bilateral } \\
\text { negotiation }\end{array}$ \\
\hline
\end{tabular}

Source: Authors' own. Created using data from Meyer et al. (2018) and Eberhard et al. (2016)

Clearly reforms helped the Ugandan electricity sector to attract investments and increase generation capacity. Table 4.1 shows the projects with direct Chinese involvement and financing in power generation in Uganda. The electricity sector has a good mix of typical IPP projects and Chinese funded generation projects, but the latter are focused on hydro projects. By mid-2022, China is expected to have invested over US\$1.917bn in Ugandan power generation and will be contributing 39 per cent of the country's power installed capacity. China also participated in Ugandan power generation as an EPC contractor and equipment manufacturer for power plants not directly financed by China. Whereas it is uncontested that China has made a significant contribution to the Ugandan power sector, it has also contributed to the Ugandan debt burden, as in many other SSA countries. According to the IMF, the Ugandan debt to GDP ratio was 44.81 per cent in 2020, largely due to borrowing from China for infrastructure development. As far as Chinese finance in the energy sector is concerned, the Ugandan government is the borrower and carries the obligation of repaying the loan, supplemented by revenue from the projects. In order to ensure loan repayment, the government is required to allocate funds every fiscal year through the National Budget for debt service. 


\section{Discussion and conclusion}

The evidence we generated at SSA level and from Ethiopia and Uganda show that Chinese finance has provided the much-needed investments to bridge the financing gaps in the SSA power infrastructure, and significantly contributed to the expansion of the region's power generation capacity. However, Chinese finance has also, inadvertently, exacerbated the fragile external public debt situation of SSA. Ethiopia and Uganda each owe at least US\$2bn to their Chinese financiers. Second, despite China's unparalleled financial and technological capabilities in renewables such solar and wind technologies (Lema et al. 2021; Ayele et al. 2021), Chinese finance predominantly went to hydropower generation, which is vulnerable to climate change (and, at worst, coal-based electricity generation - which is the single biggest contributor to environmental pollution and climate change). At the heart of our conclusion was that the EPC model was pursued by Chinese businesses, China predominantly invests in hydropower projects, and does not participate in competitive procurement as it prefers country bilateral negotiations. But why do Chinese business prefer EPC projects that lead to debt for host governments? Based on the evidence we analysed, and complemented by other studies (such as Lema et al. 2021; Ayele et al. 2021), we offer the following explanations and conclusions:

Lower transaction costs and bureaucracy: Electricity generation though IPPs is subject to a long, and transparent, process of auctions, but EPC projects appear to be quick to start moving. Moreover, under the IPP model, project finance relies on project generated finance which creates incentives for host countries to reform the power supply value chain before the investment is signed up (to ensure financial sustainability), hence this model may have the effect of delaying project implementation. However, Chinese businesses engaged in renewables appear to be on a learning curve and, despite having unprecedented technological capabilities, they have not previously engaged in the competitive (IPP) power generation model. They appear to prefer the EPC model, which does not necessarily require competition and a commitment to transparency procedures for approval. A widely reported case (see, for example, Meyer et al. 2018) reaffirms our claim here. Uganda's president, Yoweri Museveni, used the 2013 Durban BRICS conference and a meeting with Chinese President Xi Jinping to award the Karuma plant to Sinohydro and the Isimba to CWE. Meyer et al. (2018) states that the award to Sinohydro came as a surprise, as the company had never been a short-listed bidder for Karuma, and it remains unclear on which assessments the award was obtained. Overall, because lower transaction costs are involved, Chinese EPC model projects give the impression of being cheaper compared to projects finance by IPPs. Under IPP project 
finance, the lenders require that equity is drawn first and fully before the loan. The accrued compounded equity during construction increases project development costs. In the case of many Chinese EPC model projects, as our evidence from Ethiopia and Uganda show, governments raise about 15 per cent upfront finance which does not attract interest during construction.

Risk allocation: Project development risks (construction delays, cost overruns, licensing, etc.) and project operation risks (such as revenue risk, supplier risk, and foreign exchange risk) apply to both Chinese-financed EPC projects and IPP projects. However, under the Chinese EPC model, EPC contractors are not required to do the so-called BOOTs - build, own, operate and transit arrangements. The debt burden is negotiated government-to-government, or with respective government agencies. Chinese-funded EPCs are typically handed over to SSA government or government-appointed utilities at commercial operations date. This risk allocation framework explains why China prefers the EPC model for infrastructure projects in SSA. That said, Chinese-financed power generation investments are not immune to the project development risks of construction. The facts suggest that many projects in SSA (whether financed through IPPs or EPC finance) have experienced cost overruns and project delays. This is notwithstanding the fact that the interest rates for Chinesefinanced power plants are much lower than the interest rates for traditional project finance IPPs. In deciding financing of power projects, SSA policy makers should consider the costing of Chinese-financed projects beyond the interest rates provided in the loan agreements and consider the fiscal impact of the financing and national debt sustainability.

Local level development and capacity building: Studies (see, for example, Lema et al. 2021) show rather limited stakeholder engagement, limited consultation between local actors and Chinese businesses, and limited capacity building. The resources (labour and machinery/equipment) used for constructing the Chinese-funded infrastructure projects in SSA are mainly imported from China with very little support to local manufacturing and limited capacity building. During negotiations with SSA governments, China ensures that it retains the flexibility to import project inputs from China. The approach of pegging financing to Chinese funding, to Chinese equipment and contractors, is part of the holistic approach by China to support Chinese manufacturers and expand its technology and influence.

Perverse arguments: Related to the above, here critics effectively argue that the Chinese government and Chinese businesses pursue their own selfinterests. Pairault (2020) argues that the Chinese strategy or model of 'infrastructure-led growth' seems to be showing its limits in Africa, where China has largely been instrumental in promoting it. Pairault argues that, whether or not Chinese investment is redundant in the host country, the ultimate beneficiary is 
China. China maintains the supply of the goods and services that EPC projects require and keeps its GDP growing. For China, EPC projects procure suppliers from home - effectively 'tying' projects to arrangements in which recipients have no say. Fox (2019) agrees - although not an explicit (or deliberate) policy, China contributes to mounting debt in Africa.

While the explanation for Chinese businesses' preference for EPC models over IPPs is still emerging ${ }^{5}$, it is clear that the perceived convenience of the Chinese financing model may not necessarily guarantee transition to renewable energy sources and promote sustainable development in SSA power sectors. SSA implementation of IPPs was meant, in part, to reduce national burden and sustainable transition to renewable energy sources. Despite making significant contributions to energy generation, China-financed investment in the region has not made major impacts on either of the stated goals of governments in SSA. Policy makers in SSA appear to believe that Chinese-financed power generation investments are convenient, and even cheaper, compared to those by IPPs, but this needs a (re)evaluation as there are higher fiscal impacts on government cash flows, debt repayment, etc. By implementing the Chinese EPC model that requires national budget appropriation for debt repayment of Chinese-funded projects, SSA could indirectly implement policy reversals by provision of subsidies where revenue from the Chinese-funded projects is not sufficient for debt repayment. While recognising that the competitive model of power generation is not without limitations, the paper recommends increased involvement of Chinese investment in this model, with more diversification of Chinese investment portfolios towards modern renewables such wind and solar energy resources.

\footnotetext{
${ }^{5}$ It is also not yet clear whether it is the underlying limitations of many SSA counties such as inadequate policy signalling that has led Chinese businesses to opt for EPC projects. In some countries, for example, Ethiopia depended on hydropower for its power generation, and diversification to other renewables such as wind, solar, and geothermal is a relatively recent development.
} 


\section{References}

Acker, K.; Brautigam, D. and Huang, Y. (2021) 'The Pandemic has Worsened Africa's Debt Crisis. China and Other Countries are Stepping In', The Washington Post, February 26 (accessed 30 September 2021)

AfDB (2019) Estimating Investment Needs for the Power Sector in Africa 2016-2025, African Development Bank Group (accessed 30 September 2021)

AfDB (2015) The New Deal on Energy for Africa: A Transformative Partnership to Light Up and Power Africa by 2025, Abidjan: African Development Bank Group (accessed 16 March 2021)

Ayele, S.; Shen, W.; Chiyemura, F. and Gu, J. (2021) 'Enhancing China-Africa Cooperation in the Renewable Energy Sector', IDS Policy Briefing 176, Brighton: Institute of Development Studies (accessed 30 September 2021)

Ayele, S. (2021) 'The Resurgence of Agricultural Mechanisation in Ethiopia: Rhetoric or Real Commitment?', The Journal of Peasant Studies, DOI: 10.1080/03066150.2020.1847091 (accessed 30 September 2021)

Baker, L.; Shen, W. and Ayele, S. (2021, forthcoming) 'Procurement of Renewable Electricity Amid Power Sectoral Reforms: A Comparative Review of China, South Africa and Ethiopia'

Blimpo, M.P. and Cosgrove-Davies, M. (2019) Electricity Access in Sub-Saharan Africa. Uptake, Reliability, and Complementary Factors for Economic Impact, Africa Development Forum, Washington DC: International Bank for Reconstruction and Development / The World Bank, DOI: 10.1596/978-1-46481361-0 (accessed 30 September 2021)

Cabré, M.M.; Gallagher, K.P. and Li, Z. (2018) 'Renewable Energy: The Trillion Dollar Opportunity for Chinese Overseas Investment', China \& World Economy 26.6: 27-49, DOI: 10.1111/cwe.12260 (accessed 30 September 2021)

Carbis Bay G7 Summit Communiqué (2017) Our Shared Agenda for Global Action to Build Back Better, Cornwall: G7 (accessed 7 September 2021)

Chen, W.; Dollar, D. and Tang, H. (2018) 'Why is China Investing in Africa? Evidence from the Firm Level', The World Bank Economic Review 32.3: 610-32, DOI: 10.1093/wber/lhw049 (accessed 30 September 2021)

China Africa Research Initiative (2021) China-Africa Trade, China-Africa Research Initiative at Johns Hopkins University's School of Advanced International Studies (accessed 20 September 2021)

Chiyemura, F. (2019) 'The Winds of Change in Africa-China Relations? Contextualising African Agency in Ethiopia-China Engagement in Wind Energy Infrastructure Financing and Development', PhD dissertation, The Open University (accessed 30 September 2021)

Coulibaly, B.S. (2021) Debt Sustainability and Financing for Development: A Key Post-COVID Challenge, Africa in Focus, Washington DC: The Brookings Institution (accessed 17 October 2021)

Eberhard, A. Gratwick, K., Morella, E. and Antmann, P. (2017) 'Independent Power Projects in SubSaharan Africa: Investment Trends and Policy Lessons', Energy Policy 108: 390-424, DOI: 10.1016/j.enpol.2017.05.023 (accessed 5 October 2021)

Eberhard, A.; Gratwick, K.; Morella, E. and Antmann, P. (2016) Independent Power Projects in SubSaharan Africa - Lessons from Five Key Countries, Washington DC: International Bank for Reconstruction and Development / The World Bank (accessed 5 October 2021)

Electricity Regulatory Authority (2021) Installed Capacity, Electricity Regulatory Authority, 28 January (accessed 20 September 2021)

Fox, J. (2019) 'Ethiopia and the Chinese Dream in Africa', Raidió Teilifís Éireann (RTE), 23 April (accessed 30 September 2021)

Godinho, C. and Eberhard, A. (2019) Learning from Power Sector Reform Experiences: The Case of Uganda, Policy Research Working Paper 8820, Washington DC: Word Bank (accessed 30 September 2021) 
Chinese-Funded Electricity Generation in Sub-Saharan Africa and Implications for Public

Debt and Transition to Renewable Energy

Gu, J. (2009) 'China's Private Enterprises in Africa and the Implications for African Development', The European Journal of Development Research 21: 570-87, DOI: 10.1057/ejdr.2009.21 (accessed 5 October 2021)

Gu, J.; Renwick, N. and Xue, L. (2018) 'The BRICS and Africa's Search for Green Growth, Clean Energy and Sustainable Development', Energy Policy 120: 675-83, DOI: 10.1016/j.enpol.2018.05.028 (accessed 5 October 2021)

IEA (2020) World Energy Outlook 2020, Paris: International Energy Agency (accessed 30 September 2021)

IEA (2016) Boosting the Power Sector in Sub-Saharan Africa: China's Involvement, IEA Partner Country Series, Paris: International Energy Agency (accessed 30 September 2021)

IEA (2014) Africa Energy Outlook-a Focus on Energy Prospects in Sub-Saharan Africa, World Energy Outlook Special Report, Paris: International Energy Agency (accessed 30 September 2021)

IRENA (2019) Scaling up Renewable Energy Deployment in Africa: Impact of IRENA's Engagement, Abu Dhabi: International Renewable Energy Agency (accessed 30 September 2021)

IRENA and CEM (2015) Renewable Energy Auctions - A Guide to Design, Abu Dhabi: International Renewable Energy Agency (accessed 30 September 2021)

Kaplinsky, R. and Morris, M. (2009) 'Chinese FDI in Sub-Saharan Africa: Engaging with Large Dragons', European Journal of Development Research 21: 551-69, DOI: 10.1057/ejdr.2009.24 (accessed 5 October 2021)

Lema, R.; Bhamidipati, P.L.; Gregersen, C.; Hansen, U.E. and Kirchherr, J. (2021) 'China’s Investments in Renewable Energy in Africa: Creating Co-benefits or just Cashing-in?' World Development 141.105365, DOI: 10.1016/j.worlddev.2020.105365 (accessed 5 October 2021)

MEMD (2002) Energy Policy for Uganda, Kampala: The Republic of Uganda Ministry of Energy and Mineral Development

Meyer, R.; Eberhard, A. and Gratwick, K. (2018) 'Uganda’s Power Sector Reform: There and Back Again?', Energy for Sustainable Development 43: 75-89, DOI: 10.1016/j.esd.2017.11.001 (accessed 5 October 2021)

MoFEC (2017) Public-Private Partnership Policy, Addis Ababa: The Ministry of Finance and Economic Cooperation of the Federal Democratic Republic of Ethiopia

Mohan, G. (2013) 'Beyond the Enclave: Towards a Critical Political Economy of China and Africa', Development and Change 44.6: 1255-72, DOI: 10.1111/dech.12061 (accessed 5 October 2021)

MoWIE (2020) Ten Year (2013-2022 Ethiopian Calendar) Development Plan, Addis Ababa: The Federal Democratic Republic of Ethiopia Ministry of Water, Irrigation and Energy

MoWIE (2019) National Electrification Program 2.0, Addis Ababa: The Federal Democratic Republic of Ethiopia Ministry of Water, Irrigation and Energy

MoWIE (2018) National Energy Policy (Revised), Addis Ababa: The Federal Democratic Republic of Ethiopia Ministry of Water, Irrigation and Energy

Pairault, T. (2020) 'China's Infrastructure-Heavy Model for Africa Growth is Failing', The Diplomat, 30 July (accessed 30 September 2021)

Power Futures Lab (2020) Prospects for Private Power Investments in Sub-Saharan Africa in the New Decade, Cape Town: University of Cape Town (accessed 30 September 2021)

Shen, W. (2020) 'China's Role in Africa’s Energy Transition: A Critical Review of its Intensity, Institutions, and Impacts', Energy Research \& Social Science 68.101578, DOI: 10.1016/j.erss.2020.101578 (accessed 5 October 2021)

Shen, W. and Power, M. (2017) 'Africa and the Export of China's Clean Energy Revolution', Third World Quarterly 38.3: 678-97, DOI: 10.1080/01436597.2016.1199262 (accessed 5 October 2021)

Shendy, R.; Kaplan, Z. and Mousley, P. (2011) Towards Better Infrastructure. Conditions, Constraints, and Opportunities in Financing Public-Private Partnerships in Selected African Countries, World Bank Study, Washington DC: World Bank (accessed 5 October 2021)

Tan-Mullins, M.; Urban, F. and Mang, G. (2017) 'Evaluating the Behaviour of Chinese Stakeholders Engaged in Large Hydropower Projects in Asia and Africa', The China Quarterly 230: 464-88, DOI: 10.1017/S0305741016001041 (accessed 5 October 2021) 
Teferra, M. (2002) 'Power Sector Reforms in Ethiopia: Options for Promoting Local Investments in Rural Electrification', Energy Policy 30: 967-75, DOI: 10.1016/S0301-4215(02)00051-4 (accessed 5 October 2021)

Tesfamichael, M.; Mulugetta, Y.; Beyene, A.D. and Sebsibie, S. (2021) 'Counting the Cost: Coping with Tariff Increases Amidst Power Supply Shortfalls in Urban Households in Ethiopia', Energy Research \& Social Science 71.101860, DOI: 10.1016/j.erss.2020.101860 (accessed 30 September 2021)

UBOS (2020) Statistical Abstract, Kampala: Uganda Bureau of Statistics (accessed 17 October 2021) UBOS (2018) Energy for Rural Transformation (ERT III) Survey - Uganda, Kampala: Uganda Bureau of Statistics

UNECA (2014) Economic Report on Africa 2014: Dynamic Industrial Policy in Africa, Addis Ababa: United Nations Economic Commission for Africa (accessed 30 September 2021)

Wamukonya, N. (2005) 'Power Sector Reforms in Sub-Saharan Africa: Some Lessons', Economic and Political Weekly 40.50: 5302-8 (accessed 30 September 2021)

World Bank (2018) Environmental and Social Systems Assessment (ASSA) for the Ethiopian Electrification Program (ELEAP), Report No. 119032-ET, Washington DC: The World Bank (accessed 24 March 2021) 


\section{(-) institute of development studies}

Delivering world-class research, learning and teaching that transforms the knowledge, action and leadership needed for more equitable and sustainable development globally.

Institute of Development Studies

Library Road

Brighton, BN1 9RE

United Kingdom

+44 (0)1273606261

ids.ac.uk

Charity Registration Number 306371

Charitable Company Number 877338

(C) Institute of Development Studies 2021 